\title{
Attempts of Physical Refining of Sterol-Rich Sunflower Press Oil to Obtain Minimally Processed Edible Oil
}

\author{
Aída García-González ${ }^{1}$, Joaquín Velasco ${ }^{1}$ (D) Leonardo Velasco $^{2}$ (D) and M. Victoria Ruiz-Méndez ${ }^{1, *(D)}$ \\ 1 Instituto de la Grasa, Consejo Superior de Investigaciones Científicas (CSIC), Campus/Bd 46, \\ Ctra. de Utrera km 1, E-41013 Sevilla, Spain; aida.garcia@csic.es (A.G.-G.); jvelasco@ig.csic.es (J.V.) \\ 2 Instituto de Agricultura Sostenible, Consejo Superior de Investigaciones Científicas (CSIC), \\ Alameda del Obispo s/n, E-14004 Córdoba, Spain; lvelasco@ias.csic.es \\ * Correspondence: mvruiz@ig.csic.es; Tel./Fax: +34-954-61-15-50
}

check for updates

Citation: García-González, A.; Velasco, J.; Velasco, L.; Ruiz-Méndez, M.V. Attempts of Physical Refining of Sterol-Rich Sunflower Press Oil to Obtain Minimally Processed Edible Oil. Foods 2021, 10, 1901. https:/ / doi.org/10.3390/foods10081901

Academic Editors: Amparo Alegria,

Antonio Cilla and

Guadalupe Garcia-Llatas

Received: 30 July 2021

Accepted: 12 August 2021

Published: 16 August 2021

Publisher's Note: MDPI stays neutral with regard to jurisdictional claims in published maps and institutional affiliations.

Copyright: (c) 2021 by the authors. Licensee MDPI, Basel, Switzerland. This article is an open access article distributed under the terms and conditions of the Creative Commons Attribution (CC BY) license (https:/ / creativecommons.org/licenses/by/ $4.0 /)$.

\begin{abstract}
New phytosterol (PS)-enriched sunflower seeds, which are higher in campesterol and $\Delta 7$ stigmastenol, have recently been developed. Crude oils obtained from these new sunflower seeds in 2015 and 2017 were used in this study. Oils extracted only by press (PO) and with subsequent solvent extraction (SO) were characterized. Physical refining (PhR) was used to obtain edible PO by minimal processing and to keep the PS levels as high as possible. Oils obtained by chemical processing were also studied for comparative purposes. Different bleaching treatments were examined to reduce the contents of phospholipids in the PO to levels required for PhR $\left(<10 \mathrm{mg} \mathrm{kg}^{-1}\right)$. Phosphorous levels in PO from 2015 (9-12 $\mathrm{mg} \mathrm{kg}^{-1}$ ) were reduced to optimal levels by bleaching with $0.1 \%$ Trisyl and 1\% Tonsil 278 FF. Contrarily, treatments with Trisyl and Tonsil (278 FF or 114 FF) were not sufficient to reduce the higher levels in PO from $2017\left(15-36 \mathrm{mg} / \mathrm{kg}^{-1}\right)$, thereby they were subjected to chemical refining (ChR). The PhR applied to PO from 2015 did not lead to substantial changes in the composition and total content of PS. In contrast, losses of up to approximately $30 \%$ of total PS were found owing to $\mathrm{ChR}$, although the oils preserved their unique PS profiles.
\end{abstract}

Keywords: PS-enriched food; phytosterols; sunflower oil; refined oil; physical refining; chemical refining

\section{Introduction}

Plant sterols or phytosterols (PS) are compounds with proven health benefits [1,2]. Their richest natural sources are vegetable oils, followed by nuts and legumes [1]. Extracted from plants, free PS are widely used in fortified foods and dietary supplements. In most cases, free PS are extracted using organic solvents that are harmful to human health as well as to the environment [3]. The food industry is currently facing the challenge of obtaining foods enriched with bioactive compounds while applying minimal processing $[4,5]$. In this context, the production of PS-enriched seeds may be a good option to increase PS in our diet simply through the intake of vegetable oils [6-10].

The industrial production of sunflower seeds and sunflower oils is of great relevance worldwide [11]. In Europe, sunflower oil is the second most produced oleaginous seed oil and accounts for approximately $30 \%$ of the whole oil production [12]. Numerous studies on the production and characterization of edible sunflower oils with modified fatty acid compositions have been reported [13,14]. In addition, the development of oils containing modified tocopherols has been the goal of extensive research $[15,16]$. However, studies related to sunflower oils from seeds enriched in PS are limited $[9,10]$. In this respect, there are inherent difficulties in obtaining PS-enriched oils as the content of PS in seeds increases rapidly during the first seed growing stages, when the oil content in the seed is still low, and then the increase rate of PS becomes much slower as compared to that of the oil $[9,10]$. The PS composition can be also changed [17] and this could be of great interest in order to adapt sunflower oils to specific nutritional demands. Recently, new lines of PS-enriched 
seeds with increased levels of campesterol and $\Delta 7$-stigmastenol, respectively, have been developed $[9,10]$.

At the industrial level, sunflower oil production consists of extraction by press (around $70-80 \%$ of the total oil is extracted) followed by solvent extraction (hexane) of the remaining oil. Both the press oil (PO) and solvent oil (SO) are blended to produce what is known as crude oil, which must then be refined for edible purposes [13].

Oils obtained by pressing are highly demanded [18,19]. The fact that POs are obtained without the use of organic solvents raises the question of whether it is worth commercializing them separately in sunflower oil production to obtain added-value environmentally friendly oils. However, the composition of minor components differs between POs and SOs [20-22]. Specifically, total PS contents in oils from PS-enriched seeds have been reported to range from 2839 to $5284 \mathrm{mg} \mathrm{kg}^{-1}$ for POs and from 4849 to $9249 \mathrm{mg} \mathrm{kg}^{-1}$ for SOs [23]. Most importantly, it would be not possible to commercialize POs as unrefined or virgin oils due to their high content in phosphorus $(\mathrm{P})$ and metals, beyond the levels allowed by regulations [24]. While chemical refining (ChR) is imperative in SOs because of its high levels of $\mathrm{P}$, the application of a physical refining (PhR) process to POs when the acidity is low could be an alternative in order to preserve PS, which are otherwise significantly lost during chemical neutralization [25-33].

$\mathrm{PhR}$ basically consists of a bleaching step followed by neutralizing deodorization in which the free fatty acids are removed by steam distillation at low pressures (2-6 mbar) and high temperatures $\left(180-270{ }^{\circ} \mathrm{C}\right)$. Compared to $\mathrm{ChR}, \mathrm{PhR}$ reduces the loss of neutral oil and allows for the recovery of free fatty acids with minimal production of pollutants $[34,35]$. The reduction of phospholipids to levels below $10 \mathrm{mg} \mathrm{kg}^{-1}$ oil is crucial for $\mathrm{PhR}$ because phospholipids promote browning during deodorization [34-36].

The removal of low contents of $\mathrm{P}$ and metal traces can be achieved by applying specific bleaching treatments [37-39]. Bleaching is considered an adsorption purification process by which, along with pigments, a wide range of undesirable components are removed prior to deodorization, including oxidation products, trace metals and other contaminants [37,40]. A treatment with amorphous silica has been reported as a dry degumming process, presenting reductions of $\mathrm{P}$ higher than $85 \%$ and, thus, avoiding wetdegumming [38,41]. Similar reductions have also been observed for iron [41-43]. In this respect, bleaching using combinations of earths and silica could be employed to remove the low levels of P found in POs from new PS-enriched sunflower seeds [23], as well as trace metals to meet the levels allowed in the regulation [24].

The objective of this work was to study the feasibility of $\mathrm{PhR}$, bleaching and distillation to obtain edible POs from new PS-enriched sunflower seeds, thus avoiding chemical treatments. Based upon physical procedures only, the whole process would meet two of the most current consumer demands. On the one hand, oils containing high PS contents naturally would be produced by mechanical means and, on the other hand, a minimal refining processing would be required as compared to classical $\mathrm{ChR}$. The oils obtained from two different harvests, 2015 and 2017, which were characterized in a previous report [23], were studied. Different bleaching treatments in combination with amorphous silica were tested to reduce the phospholipid content to the levels required for $\mathrm{PhR}\left(\mathrm{P}<10 \mathrm{mg} \mathrm{kg}^{-1}\right.$ of oil). For comparative purposes, $\mathrm{ChR}$ and $\mathrm{SOs}$ were also investigated to weigh up the pros and cons of considering PO and SO separately in terms of PS levels. The effects of the refining processes on components of interest other than PS, such as fatty acid composition and $\alpha$-tocopherol contents, were also evaluated.

\section{Materials and Methods}

\subsection{Chemicals}

5- $\alpha$-cholestan-3-ol and tocopherols $(\alpha, \beta, \gamma, \delta)$ were standards (Purity $99 \%$ ) supplied by Sigma-Aldrich Corp. (St. Louis, MO, USA). N,O-Bis(trimethylsilyl) trifluoro acetamide with $1 \%$ trimethyl chlorosilane was used as a silanization reagent and purchased from Supelco Inc. (Bellefonte, PA, USA). All other chemicals and reagents were of analytical grade and 
were acquired from local suppliers. Trisyl ${ }^{\circledR}$ (GRACE and Co., Columbia, MD, USA) and bleaching earths (Tonsil Optimum 278 FF and Tonsil Supreme 114 FF) were supplied by Clariant Iberica Prod. SA (Toledo, Spain).

\subsection{Oil Samples}

The crude oils were those characterized in a previous report [23]. They were obtained by press and subsequent solvent extraction, respectively, from PS-enriched sunflower seeds that were rich in campesterol (CAM) and $\triangle 7$-stigmastenol (STIG), respectively, and from seeds with conventional content and composition of PS, referred to as the control (CON) following the operation conditions described in a previous report [23]. The seeds were harvested in 2015 and 2017, respectively.

\subsection{Physical Refining}

\subsubsection{Bleaching}

Several bleaching tests were carried out, combining silica gel (Trisy ${ }^{\circledR}$, Grace and co. Columbia, MD, USA) and different amounts of bleaching earth differing in the degree of activation (Table 1). The bleaching earths were bentonites (CAS Number: 70131-50-9): Tonsil optimum 278 FF (pH 5-7, 10\% suspension, filtered) and a very highly active adsorbent, Tonsil supreme $114 \mathrm{FF}$ ( $\mathrm{pH}$ 2.5-3.5, 10\% suspension, filtered), both from Sud-Chemie Adsorbents, Inc. (Germany).

Table 1. Proportions of agents used in the different bleaching treatments.

\begin{tabular}{ccccc}
\hline & Treatment & Trisyl (\%) & Tonsil 114 FF (\%) & Tonsil 278 FF (\%) \\
\hline Physical refining & TR1 & 0.1 & - & 1.0 \\
& TR2 & 0.1 & 1.0 & - \\
& TR3 & 0.2 & 2.0 & - \\
\hline Chemical & TR4 & 0.2 & 1.0 & - \\
refining & TR5 & 0.3 & 1.0 & - \\
& TR7 & 0.2 & 2.0 & - \\
\hline
\end{tabular}

The procedure used was based on the one proposed in Annexed XIII of Regulation (CEE) $\mathrm{N}^{\circ} .2568 / 91$. The oil sample was placed in a flask and heated at $95^{\circ} \mathrm{C}$ under stirring and vacuum conditions. When the set temperature was reached, Trisy $1^{\circledR}$ and the bleaching earth were added. The vacuum was restored and stirring at $95^{\circ} \mathrm{C}$ was kept for $10 \mathrm{~min}$. Then the oil was filtered with a MilliPore filter under vacuum. Phosphorous and metal removal was used as a control parameter.

\subsubsection{Neutralization/Deodorization}

A steam distillation process was carried out at $200^{\circ} \mathrm{C}$ for $2 \mathrm{~h}$ by applying a vacuum of $0.5-1 \mathrm{mmHg}$. The source of water vapor was supplied with a peristaltic pump. The water was passed through a separator with controlled temperature and finally introduced through a diffuser into a round flask containing the oil ( $500 \mathrm{~g})$, applying a steam flow of $0.50 \mathrm{~mL} \mathrm{~min}^{-1}$. Then the oil was cooled and using nitrogen we stopped the vacuum. The deodorized oil was filtered with a filter paper and stored at $5{ }^{\circ} \mathrm{C}$ until the analyses.

\subsection{Chemical Refining}

\subsubsection{Phosphoric Degumming}

Phosphorous compounds in the oils were precipitated with phosphoric acid in water $(1: 1 w / w)$ at $0.1 \%(w / w)$ for PO and $0.2 \%(w / w)$ for SO. The oil/water mixture was vigorously stirred at $40{ }^{\circ} \mathrm{C}$ in a paddle stirrer for $5 \mathrm{~min}$. 


\subsubsection{Neutralization}

Without separating the gums from the previous stage, sodium hydroxide was added at different concentrations, depending on the acidity level, so as to be sufficient to neutralize the FFA and the mineral acid added, plus a 10\% excess for ensuring the formation of soaps. The sodium hydroxide addition was carried out while stirring at $40{ }^{\circ} \mathrm{C}$. The temperature was then raised to $80^{\circ} \mathrm{C}$ and held for $10 \mathrm{~min}$. The resulting soaps, along with the phospholipids hydrated in the previous step, were removed by washing and centrifugation. Centrifugation was carried out at $1295 \times \mathrm{g}$ for $10 \mathrm{~min}$.

\subsubsection{Washes}

The oils obtained in the previous stage were washed at $90{ }^{\circ} \mathrm{C}$ using water at $15 \%$ $(w / w)$. Stirring for $10 \mathrm{~min}$ was applied. The water was then separated by centrifugation at $1295 \times g$ for $10 \mathrm{~min}$. Three successive washing operations were applied to remove the soap completely.

\subsubsection{Bleaching and Deodorization}

The bleaching and deodorization stages were performed as indicated for PhR.

\subsection{Analytical Methods}

\subsubsection{Elemental Analysis}

The elemental analysis of metal and non-metal traces-As, $\mathrm{Ca}, \mathrm{Cu}, \mathrm{Fe}, \mathrm{K}, \mathrm{Mg}, \mathrm{Na}, \mathrm{P}, \mathrm{Pb}$, $\mathrm{S}$ and $\mathrm{Zn}$-was determined by Inductively Coupled Plasma-Optical Emission Spectrometry (ICP-OES) on a Varian ICP 720-ES axial configuration device at the Institute of Natural Resources and Agrobiology (CSIC) (Seville, Spain). SRM 1573a (Tomato Leaves) and an interlaboratory sample (SE 2016 IPE-WEPAL) from the University of Wageningen were used as reference materials.

\subsubsection{Analysis of Chlorophylls}

Quantitative determination of chlorophylls in the oils was carried out by spectrophotometry at $670 \mathrm{~nm}$ according to Pokorný et al. [44]. Measurements were performed in cyclohexane using $0.3 \mathrm{~g} \cdot \mathrm{mL}^{-1}$ solutions. A Genesys $10 \mathrm{UV}$ spectrophotometer was used.

\subsubsection{Acidity}

Acidity was determined by titration following the ISO Standard Method 660:2020 [45].

\subsubsection{Fatty Acid Composition and PS Contents}

The fatty acid composition and the levels of PS were determined according to a method developed in our lab [46], based on a transmethylation reaction of the oil sample followed by a SPE fractionation $\left(\mathrm{NH}_{2}-500 \mathrm{mg}\right.$ ). Two fractions comprising the fatty acid methyl esters and the PS, respectively, were obtained and analyzed by gas liquid chromatography (GLC) [46].

For analysis of fatty acid composition, an Agilent Technologies (AT) 6890 chromatograph equipped with a split/splitless injector, an AT INNOWAX capillary column (100 $\mathrm{m} \times 0.25 \mathrm{~mm}$ i.d., $\times 0.25 \mu \mathrm{m}$ film thickness) and a flame ionization detector (FID) was used. Hydrogen at a flow rate of $1.2 \mathrm{~mL} \cdot \mathrm{min}^{-1}$ was used as carrier gas. The injector temperature was $225^{\circ} \mathrm{C}$ and a 40:1 split ratio was applied. The oven temperature was kept at $180^{\circ} \mathrm{C}$ for $9 \mathrm{~min}$. Then the temperature was increased to $220^{\circ} \mathrm{C}$ at $3^{\circ} \mathrm{C} \cdot \mathrm{min}^{-1}$ and held for $15 \mathrm{~min}$. The FID temperature was set at $250^{\circ} \mathrm{C}$.

For the analysis of PS, the elution solvent was removed at $60^{\circ} \mathrm{C}$ under vacuum in a rotary evaporator. The dried extract was silanized and analyzed by GLC. An AT 7890A chromatograph was used, equipped with a split/splitless injector, a capillary column of fused silica HP-5 (5\% diphenyl-94\% dimethyl- $1 \%$ vinylpolysiloxane, $30 \mathrm{~m} \times 0.32 \mathrm{~mm}$ i.d. $\times 0.25 \mu \mathrm{m}$ film thickness) and an FID. The injector temperature was $275^{\circ} \mathrm{C}$ and a $20: 1$ split ratio was used. The oven temperature was $260^{\circ} \mathrm{C}$ (isothermal conditions) and the analysis took 
$40 \mathrm{~min}$. The detector temperature was $320^{\circ} \mathrm{C}$. Hydrogen was used as a carrier gas at a constant pressure of 15 psi.

\subsubsection{Tocopherols}

Tocopherols were determined by HPLC with fluorescence detection following the ISO standard method 9936:2016 [47]. The oil samples dissolved in n-heptane $\left(50 \mathrm{mg} \cdot \mathrm{mL}^{-1}\right)$ were directly analyzed in an Agilent 1260 Infinity HPLC chromatograph (Agilent Technologies, USA) equipped with a quaternary pump VL (G1311C), a standard autosampler (G1329B), a thermostatted column compartment (TCC) (G1316A) and a fluorescence detector (G1321A). A silica HPLC column (LiChrospher ${ }^{\circledR}$ Si $60,250 \mathrm{~mm} \times 4 \mathrm{~mm}$ i.d., $5 \mu \mathrm{m}$ particle size) (Merck, Darmstadt, Germany) was used. The volume of the sample analyzed was $20 \mu \mathrm{L}$. The temperature of the TCC was set at $25^{\circ} \mathrm{C}$. The separation of tocopherols was performed using n-heptane:isopropanol $(99: 1, v / v)$ with a flow rate of $1 \mathrm{~mL} \cdot \mathrm{min}^{-1}$. The excitation and emission wavelengths in the detector were $290 \mathrm{~nm}$ and $330 \mathrm{~nm}$, respectively. Quantification was done by external calibration using tocopherol standards.

\subsection{Statistical Analyses}

The statistical program SPSS (SPSS Inc., Chicago, IL, USA), version 24.0, was used to evaluate the influence of the refining process, considering significance for a probability greater than $95 \%(p<0.05)$. The influence of the refining treatment on the different samples analyzed was evaluated by applying the Student's $t$ test.

\section{Results and Discussion}

\subsection{Bleaching Assays}

The POs obtained in harvests from 2015 and 2017 showed different responses to the bleaching conditions applied. The contents of $P$ in the oils from $2015\left(9.3-11.9 \mathrm{mg} \mathrm{kg}^{-1}\right)$ [23] were reduced to optimal levels for $\mathrm{PhR}\left(<10 \mathrm{mg} \mathrm{kg}^{-1}\right.$ oil $)$ by applying a bleaching treatment with a blend of Trysil and Tonsil 278 FF (TR1) (Table 2). In contrast, the relatively higher contents in the POs from 2017 (15.4-36.4 mg kg-1) as compared to those from the 2015 harvest, did not allow for appropriate reductions of $\mathrm{P}$ when treated under the same conditions.

Table 2. Phosphorous content $\left(\mathrm{mg} \mathrm{kg}^{-1}\right)$ in the press oil samples after bleaching.

\begin{tabular}{cccccc}
\hline & \multicolumn{3}{c}{ Bleaching Treatment } & \multicolumn{2}{c}{ Phosphorous (mg/kg) } \\
\cline { 2 - 6 } Oil Sample & Trisyl (\%) & Tonsil 114 FF (\%) & Tonsil 278 FF (\%) & Initial & Final \\
\hline 2015 & & & & & \\
CON & 0.1 & - & 1.0 & 11.7 & 4.2 \\
CAM & 0.1 & - & 1.0 & 9.3 & 3.7 \\
STIG & 0.1 & - & 1.0 & 11.9 & 5.9 \\
\hline C17 & & - & & & \\
CON & 0.1 & - & 1.0 & 27.3 & 24.2 \\
CAM & 0.1 & - & 1.0 & 15.4 & 10.7 \\
STIG & 0.1 & 1.0 & 1.0 & 36.4 & 30.1 \\
STIG & 0.1 & 2.0 & - & 36.4 & 28.9 \\
STIG & 0.2 & & - & 36.4 & 24.4 \\
\hline
\end{tabular}

Abbreviations: Conventional (CON), $\Delta 7$-stigmastenol-rich (STIG) and campesterol-rich (CAM) sunflower oils Results express the mean value of two determinations $(n=2)$.

Since it is known that the effectiveness of $P$ reduction is significantly affected by the composition of earths [48], an attempt was made with one of the oils changing the earth to a more activated one (Tonsil $114 \mathrm{FF}$ ) and the proportion of the bleaching agents; however, the P levels obtained were not still sufficiently low (Table 2). As discussed below, this fact could be attributed to $P$ coming from sources other than phospholipids in sunflower crude oils [49-51]. For appropriate reductions of $\mathrm{P}$, an acid degumming step seemed to be required, which would allow for reductions to levels higher than 90\% [39]. 
The SO obtained either from the 2015 or 2017 harvests presented elevated contents of $\mathrm{P}$ (263-585 $\mathrm{mg} \mathrm{kg}^{-1}$ ) [23]; hence, the only type of oil refining applicable for the optimal $P$ reduction for deodorization $\left(<10 \mathrm{mg} \mathrm{kg}^{-1}\right.$ oil) was acid degumming $[34,35,39]$. Thus, SO samples were all refined by $\mathrm{ChR}$, which consisted of acid degumming, free fatty acid chemical neutralization, bleaching and deodorization. $\mathrm{P}$ was accordingly removed by degumming and finally by bleaching treatments (Table S1), but the remaining P levels were not still adequate for deodorization. Therefore, different bleaching treatments were also examined in the degummed/neutralized oils using different proportions of Trisyl and Tonsil 114 FF (TR4-TR7). The bleaching conditions referenced as TR4 (Table 1) were those selected for refining POs (2017) and those selected as TR7 for SOs.

Table 3 shows the results for the STIG oils after acid degumming, alkali neutralization and bleaching. The levels of $\mathrm{P}$ were appropriately reduced for the PO, but the SO still presented relatively high contents with the treatments applied $\left(33.6 \mathrm{mg} \cdot \mathrm{kg}^{-1}\right)$. Nevertheless, both treatments were effective in reducing the chlorophyll contents, showing expected losses of approximately $90 \%$ [28,30].

Table 3. Influence of degumming/neutralization/bleaching on the levels of components determined by elemental analysis $\left(\mathrm{mg} \mathrm{kg}^{-1}\right)$ and of chlorophyll $\left(\mathrm{mg} \mathrm{kg}^{-1}\right)$ in the conventional (CON), $\Delta 7-$ stigmastenol-rich (STIG) and campesterol-rich (CAM) sunflower oil samples of 2017.

\begin{tabular}{cccccc}
\hline & \multicolumn{3}{c}{ Bleaching Treatment } & \multicolumn{2}{c}{ Phosphorous (mg/kg) } \\
\hline Oil Sample & Trisyl (\%) & Tonsil 114 FF (\%) & Tonsil 278 FF (\%) & Initial & Final \\
\hline 2015 & & & & & \\
CON & 0.1 & - & 1.0 & 11.7 & 4.2 \\
CAM & 0.1 & - & 1.0 & 9.3 & 3.7 \\
STIG & 0.1 & - & 1.0 & 11.9 & 5.9 \\
\hline 2017 & & - & & & \\
CON & 0.1 & - & 1.0 & 27.3 & 24.2 \\
CAM & 0.1 & - & 1.0 & 15.4 & 10.7 \\
STIG & 0.1 & 1.0 & 1.0 & 36.4 & 30.1 \\
STIG & 0.1 & 2.0 & - & 36.4 & 28.9 \\
STIG & 0.2 & - & - & 36.4 & 24.4 \\
\hline
\end{tabular}

nd, not detected. Results express the mean value of two determinations $(n=2)$.

Even though the levels of $\mathrm{P}$ were still relatively high in the degummed/neutralized/ bleached SO, no oil darkening was observed in the deodorization step. Elemental analysis also showed that metal traces decreased significantly after the treatments (Tables S1 and S2). $\mathrm{Ca}$ and $\mathrm{Mg}$ levels were higher in SO than in $\mathrm{PO}$ and both were significantly reduced (Table 3). These results are consistent with the losses of $\mathrm{P}$ because $\mathrm{Ca}$ and $\mathrm{Mg}$ are mostly complexed by phospholipids [35,50]. A significant reduction of Fe levels was also achieved in the bleached oils, showing contents below $3 \mathrm{mg} \mathrm{kg}^{-1}$, which was likewise indicative of the high efficiency of the bleaching treatments.

Given that P in the PO from the 2015 harvest was reduced by bleaching to levels below $10 \mathrm{mg} \mathrm{kg}^{-1}$, which are optimal for PhR (Table 2), the PO-CAM and PO-STIG samples obtained in the 2015 harvest were the only samples that could be refined by PhR, while those obtained in 2017 had to be refined by ChR.

\subsection{Physical Refining (PhR)}

The crude PO from the 2015 harvest met the specifications of edible virgin sunflower oils established by Codex Alimentarius with the exception of the levels of trace metals such as $\mathrm{As}, \mathrm{Pb}$ and $\mathrm{Cu}$ [23]. In terms of acidity, the low values $(<0.3 \%)$ found were far below the limit established $(\leq 2)$, but refining was absolutely necessary to meet the metal specifications. In this regard, the bleaching conditions applied to reduce the P levels were also effective to diminish the contents of metals below the specified limits (Table S1). 
The effects of PhR on the bleached oils are given in Table 4. Acidity was lower than $0.2 \%$, thus fulfilling the specifications for edible refined oils (Codex Alimentarius), which denoted that appropriate neutralizing deodorization conditions were applied.

Table 4. Influence of the physical refining (PhR) process on fatty acid composition (\%) and PS levels of the press oils of 2015 .

\begin{tabular}{ccccc}
\hline & \multicolumn{2}{c}{ CAM } & \multicolumn{2}{c}{ STIG } \\
\cline { 2 - 5 } & Bleached & Ph Refined & Bleached & Ph Refined \\
\hline Acidity (\%) & $0.26 \pm 0.03 \mathrm{a}$ & $0.15 \pm 0.05 \mathrm{~b}$ & $0.18 \pm 0.02 \mathrm{a}$ & $0.05 \pm 0.03 \mathrm{~b}$ \\
\hline Fatty acid & & & & \\
composition (\%) & & & & \\
\hline C16: 0 & $7.1 \pm 0.03 \mathrm{a}$ & $7.1 \pm 0.05 \mathrm{a}$ & $6.1 \pm 0.02 \mathrm{a}$ & $6.0 \pm 0.06 \mathrm{a}$ \\
C16: 1 & nd & nd & nd & nd \\
C18: 0 & $2.9 \pm 0.03 \mathrm{a}$ & $3.0 \pm 0.10 \mathrm{a}$ & $4.3 \pm 0.03 \mathrm{a}$ & $4.7 \pm 0.11 \mathrm{~b}$ \\
C18: 1 & $34.7 \pm 0.15 \mathrm{a}$ & $35.0 \pm 0.68 \mathrm{a}$ & $39.6 \pm 0.15 \mathrm{a}$ & $40.0 \pm 0.18 \mathrm{~b}$ \\
C18: 2 & $54.5 \pm 0.12 \mathrm{a}$ & $54.1 \pm 0.68 \mathrm{a}$ & $49.0 \pm 0.10 \mathrm{~b}$ & $48.3 \pm 0.21 \mathrm{a}$ \\
C20: 0 & $0.3 \pm 0.02 \mathrm{a}$ & $0.3 \pm 0.01 \mathrm{a}$ & $0.4 \pm 0.00 \mathrm{~b}$ & $0.3 \pm 0.03 \mathrm{a}$ \\
C22: 0 & $0.4 \pm 0.02 \mathrm{a}$ & $0.4 \pm 0.04 \mathrm{a}$ & $0.5 \pm 0.00 \mathrm{a}$ & $0.5 \pm 0.01 \mathrm{a}$ \\
C24: 0 & $0.2 \pm 0.01 \mathrm{a}$ & $0.2 \pm 0.01 \mathrm{a}$ & $0.2 \pm 0.01 \mathrm{a}$ & $0.2 \pm 0.02 \mathrm{a}$ \\
Phytosterols & & & & \\
Composition (\%) & & & & \\
Campesterol & $29.5 \pm 0.46 \mathrm{a}$ & $29.6 \pm 0.43 \mathrm{a}$ & $6.4 \pm 0.22 \mathrm{a}$ & $6.5 \pm 0.08 \mathrm{a}$ \\
Stigmasterol & $7.5 \pm 0.24 \mathrm{a}$ & $7.4 \pm 0.19 \mathrm{a}$ & $8.8 \pm 0.27 \mathrm{a}$ & $8.4 \pm 0.18 \mathrm{a}$ \\
$\beta$-Sitosterol & $47.9 \pm 0.78 \mathrm{a}$ & $48.3 \pm 0.49 \mathrm{a}$ & $49.3 \pm 0.29 \mathrm{a}$ & $49.6 \pm 0.31 \mathrm{a}$ \\
$\Delta 5$-Avenasterol & $3.3 \pm 0.12 \mathrm{a}$ & $3.3 \pm 0.11 \mathrm{a}$ & $1.2 \pm 0.09 \mathrm{a}$ & $1.2 \pm 0.04 \mathrm{a}$ \\
$\Delta 7$-Stigmastenol & $7.8 \pm 0.69 \mathrm{a}$ & $7.5 \pm 0.48 \mathrm{a}$ & $29.7 \pm 0.42 \mathrm{a}$ & $30.0 \pm 0.28 \mathrm{a}$ \\
$\Delta 7-$ Avenasterol & $4.0 \pm 0.34 \mathrm{a}$ & $3.9 \pm 0.35 \mathrm{a}$ & $4.6 \pm 0.18 \mathrm{a}$ & $4.4 \pm 0.14 \mathrm{a}$ \\
Total PS content & $3387 \pm 145 \mathrm{a}$ & $3285 \pm 56 \mathrm{a}$ & $4056 \pm 53 \mathrm{a}$ & $3818 \pm 232 \mathrm{a}$ \\
(mg kg ${ }^{-1}$ ) & & & & \\
Tocopherols & $881 \pm 22 \mathrm{a}$ & $861 \pm 21 \mathrm{a}$ & $722 \pm 18 \mathrm{a}$ & $702 \pm 17 \mathrm{a}$ \\
(mg.kg-1) & & & \\
\hline
\end{tabular}

nd, not detected. Results are expressed as mean values \pm standard deviation $(n=4$ for initial oils and $n=3$ for refined). Different letters indicate significant differences between the bleached and PhR samples $(p<0.05)$ according to the Student's $t$ test.

\subsubsection{Fatty Acid Composition}

The results obtained for the fatty acid composition indicated that the refined oils met the characteristics established for sunflower oils [13]. As expected, no substantial changes were observed between the crude and refined oils. Slight but significant $(p<0.05)$ differences were only detected in the STIG sample. Although trans fatty acids could be formed due to a high temperature [28], they were not detected due to the mild conditions applied.

\subsubsection{Phytosterols}

No significant differences were found in the total content of PS between the crude and refined oils (Table 4). These results are consistent with the mild conditions applied in the bleaching step, using a non-acid activated earth (278 FF), and in deodorization. According to Verleyen et al. [52], the main loss of PS in PhR takes place during the deodorization step, due to the removal of free PS, and mainly depends on temperature. Consequently, together with the absence of trans fatty acids, the unchanged levels of PS obtained were indicative of the mild temperature conditions applied.

Regarding the composition of PS, no significant changes were observed as a consequence of the PhR process either (Table 4). The results confirmed that the conditions selected for bleaching were not drastic enough to cause changes in PS composition due to the dehydration of the $\Delta 5$-sterols or the formation of $\Delta 7$-sterols isomers. Such reactions would have required temperatures higher than $100{ }^{\circ} \mathrm{C}$ and bleaching earths with high activity [25]. As for the deodorization step, preferential losses due to higher volatility of the 
$\Delta 5$ unsaturated PS, i.e., campesterol, stigmasterol, $\beta$-sitosterol and $\Delta 7$-avenasterol, would have been expected [27]. However, the results obtained showed that the deodorization conditions were not drastic enough to result in partial losses of PS.

\subsubsection{Tocopherols}

As found for PS, no significant losses of tocopherols were observed after PhR (Table 4). This fact further supported that the bleaching and deodorization steps were run under mild conditions. Tocopherol losses after PhR as high as $20-25 \%$, occurring basically in the deodorization step, have been reported in other studies [27-31,52]. In such cases, tocopherols were normally removed by steam distillation at a high temperature and concentrated in the distillates [7].

\subsection{Chemical Refining (ChR)}

As outlined above, the deodorization conditions applied did not result in oil darkening, even though the content of $\mathrm{P}$ was not reduced to optimal levels for deodorization $\left(<10 \mathrm{mg} \mathrm{kg}^{-1}\right)$. Considering that bleaching was effective in terms of reductions of metals, especially $\mathrm{Ca}$ and $\mathrm{Mg}$, and that most hydratable phospholipids are removed at the degumming stage, the fact that no darkening was observed during deodorization supports the hypothesis that the color could be attributed to compounds others than phospholipids [49-51].

\subsubsection{Fatty Acid Composition}

No substantial changes in fatty acid composition were observed in $\mathrm{PO}(2017)$ and $\mathrm{SO}$ as a consequence of $\mathrm{ChR}$ (Table 5). Only slight but significant $(p<0.05)$ differences were found, in particular for the major fatty acids (C18:1 and C18:2), and in PO to a greater extent.

Table 5. Influence of the chemical refining (ChR) process on the fatty acid composition (\%) of the press and solvent oils of 2017.

\begin{tabular}{|c|c|c|c|c|c|c|}
\hline & \multicolumn{2}{|c|}{ CON } & \multicolumn{2}{|c|}{ CAM } & \multicolumn{2}{|c|}{ STIG } \\
\hline & Crude & Ch Refined & Crude & Ch Refined & Crude & Ch Refined \\
\hline \multicolumn{7}{|l|}{ Press } \\
\hline Acidity (\%) & $1.00 \pm 0.05 a$ & $0.02 \pm 0.01 b$ & $0.99 \pm 0.05 a$ & $0.02 \pm 0.01 b$ & $1.10 \pm 0.05 a$ & $0.02 \pm 0.01 b$ \\
\hline \multicolumn{7}{|l|}{ Fatty Acids (\%) } \\
\hline C16: 0 & $7.0 \pm 0.01 \mathrm{a}$ & $7.0 \pm 0.01 \mathrm{a}$ & $6.5 \pm 0.01 \mathrm{a}$ & $6.6 \pm 0.00 \mathrm{~b}$ & $7.1 \pm 0.01 \mathrm{a}$ & $7.2 \pm 0.01 b$ \\
\hline C16: 1 & $0.2 \pm 0.00 \mathrm{a}$ & $0.2 \pm 0.00 \mathrm{a}$ & nd & $0.1 \pm 0.00$ & $0.1 \pm 0.00 \mathrm{a}$ & $0.1 \pm 0.00 \mathrm{a}$ \\
\hline C18: 0 & $3.6 \pm 0.01 b$ & $3.5 \pm 0.02 \mathrm{a}$ & $3.0 \pm 0.01 b$ & $2.9 \pm 0.01 \mathrm{a}$ & $4.1 \pm 0.03 \mathrm{a}$ & $4.1 \pm 0.01 \mathrm{a}$ \\
\hline C18: 1 & $30.0 \pm 0.02 \mathrm{a}$ & $30.3 \pm 0.06 b$ & $30.0 \pm 0.08 \mathrm{a}$ & $30.3 \pm 0.03 b$ & $23.8 \pm 0.02 a$ & $24.4 \pm 0.02 b$ \\
\hline C18: 2 & $57.9 \pm 0.05 b$ & $57.7 \pm 0.09 a$ & $59.5 \pm 0.09 b$ & $59.1 \pm 0.05 a$ & $63.6 \pm 0.02 b$ & $62.8 \pm 0.02 a$ \\
\hline C20: 0 & $0.3 \pm 0.00 \mathrm{a}$ & $0.3 \pm 0.01 a$ & $0.3 \pm 0.04 b$ & $0.2 \pm 0.00 \mathrm{a}$ & $0.3 \pm 0.00 \mathrm{a}$ & $0.3 \pm 0.00 \mathrm{a}$ \\
\hline C18: 3 & $0.1 \pm 0.00 \mathrm{a}$ & $0.1 \pm 0.01 \mathrm{a}$ & nd & $0.1 \pm 0.01$ & $0.1 \pm 0.00 \mathrm{a}$ & $0.1 \pm 0.01 \mathrm{a}$ \\
\hline C20: 1 & $0.2 \pm 0.00 \mathrm{a}$ & $0.1 \pm 0.01 b$ & $0.1 \pm 0.02 \mathrm{a}$ & $0.2 \pm 0.00 \mathrm{a}$ & $0.2 \pm 0.00 \mathrm{a}$ & $0.2 \pm 0.01 a$ \\
\hline C22: 0 & $0.6 \pm 0.00 \mathrm{a}$ & $0.6 \pm 0.01 \mathrm{a}$ & $0.4 \pm 0.05 b$ & $0.5 \pm 0.01 \mathrm{a}$ & $0.6 \pm 0.01 \mathrm{a}$ & $0.6 \pm 0.01 \mathrm{a}$ \\
\hline C24: 0 & $0.3 \pm 0.00 \mathrm{a}$ & $0.3 \pm 0.01 \mathrm{a}$ & $0.1 \pm 0.02 \mathrm{a}$ & $0.1 \pm 0.02 \mathrm{a}$ & $0.3 \pm 0.00 \mathrm{a}$ & $0.3 \pm 0.01 a$ \\
\hline \multicolumn{7}{|l|}{ Solvent } \\
\hline Acidity (\%) & $1.42 \pm 0.05 a$ & $0.08 \pm 0.03 b$ & $1.64 \pm 0.10 \mathrm{a}$ & $0.10 \pm 0.05 b$ & $1.55 \pm 0.05 a$ & $0.09 \pm 0.02 b$ \\
\hline \multicolumn{7}{|l|}{ Fatty Acids (\%) } \\
\hline C16: 0 & $7.3 \pm 0.0 b$ & $7.2 \pm 0.01 \mathrm{a}$ & $6.8 \pm 0.03 a$ & $6.7 \pm 0.03 a$ & $7.4 \pm 0.00 \mathrm{a}$ & $7.4 \pm 0.04 a$ \\
\hline C16: 1 & $0.2 \pm 0.00 \mathrm{a}$ & $0.2 \pm 0.01 \mathrm{a}$ & nd & $0.1 \pm 0.00 \mathrm{a}$ & $0.1 \pm 0.00 \mathrm{a}$ & $0.1 \pm 0.00 \mathrm{a}$ \\
\hline C18: 0 & $3.6 \pm 0.01 b$ & $3.5 \pm 0.01 \mathrm{a}$ & $3.2 \pm 0.01 \mathrm{a}$ & $3.1 \pm 0.04 a$ & $4.1 \pm 0.01 \mathrm{a}$ & $4.0 \pm 0.10 \mathrm{a}$ \\
\hline C18: 1 & $29.0 \pm 0.03 a$ & $29.3 \pm 0.01 b$ & $29.6 \pm 0.04 b$ & $27.9 \pm 0.07 a$ & $23.6 \pm 0.02 \mathrm{a}$ & $24.4 \pm 0.20 \mathrm{~b}$ \\
\hline C18: 2 & $58.5 \pm 0.06 a$ & $58.5 \pm 0.01 \mathrm{a}$ & $59.3 \pm 0.07 a$ & $59.3 \pm 0.09 a$ & $63.3 \pm 0.02$ & $62.7 \pm 0.38 a$ \\
\hline C20: 0 & $0.3 \pm 0.00 \mathrm{a}$ & $0.3 \pm 0.00 \mathrm{a}$ & $0.2 \pm 0.00 \mathrm{a}$ & $0.2 \pm 0.00 \mathrm{a}$ & $0.3 \pm 0.00 \mathrm{a}$ & $0.3 \pm 0.01 \mathrm{a}$ \\
\hline C18: 3 & $0.1 \pm 0.00 \mathrm{a}$ & $0.1 \pm 0.01 \mathrm{a}$ & nd & $0.1 \pm 0.01 \mathrm{a}$ & $0.1 \pm 0.00 \mathrm{a}$ & $0.1 \pm 0.00 \mathrm{a}$ \\
\hline C20: 1 & $0.2 \pm 0.00 \mathrm{a}$ & $0.2 \pm 0.00 \mathrm{a}$ & $0.2 \pm 0.00 \mathrm{a}$ & $0.2 \pm 0.00 \mathrm{a}$ & $0.2 \pm 0.00 \mathrm{a}$ & $0.2 \pm 0.01 a$ \\
\hline C22: 0 & $0.6 \pm 0.01 b$ & $0.5 \pm 0.01 \mathrm{a}$ & $0.5 \pm 0.01 \mathrm{a}$ & $0.5 \pm 0.01 \mathrm{a}$ & $0.6 \pm 0.00 \mathrm{a}$ & $0.6 \pm 0.02 a$ \\
\hline C24: 0 & $0.3 \pm 0.00 \mathrm{a}$ & $0.3 \pm 0.00 \mathrm{a}$ & $0.2 \pm 0.00 \mathrm{a}$ & $0.2 \pm 0.01 \mathrm{a}$ & $0.3 \pm 0.00 \mathrm{a}$ & $0.3 \pm 0.01 a$ \\
\hline
\end{tabular}

nd, not detected. Results are expressed as mean values \pm standard deviation ( $n=4$ for bleached oils and $n=3$ for ChR oils). Different letters indicate significant differences between bleached and ChR oils for each sample $(p<0.05)$, according to the Student's $t$ test. 


\subsubsection{Phytosterols}

As expected, significant losses of PS were observed after ChR (Table 6), ranging from $13 \%$ to $32 \%$ in POs and from $19 \%$ to $31 \%$ in SOs. Similar losses of up to $30 \%$ were found by Verhé et al. [26] and Verleyen et al. [52]. Due to the presence of a hydroxyl group, free sterols show a certain affinity to the alkaline aqueous solution, and the physical migration of phytosterols seems to be the main reason for phytosterol losses during ChR [19]. In fact, the higher the soda concentration, the higher the losses found [27,28,32,33]. In addition, some losses of PS have also been found in the bleaching and deodorization steps of different vegetable oils $[28,32]$.

Table 6. Influence of the ChR process on minor components (PS and tocopherols) of the press and solvent oils of 2017.

\begin{tabular}{|c|c|c|c|c|c|c|}
\hline & \multicolumn{2}{|c|}{$\mathrm{CON}$} & \multicolumn{2}{|c|}{ CAM } & \multicolumn{2}{|c|}{ STIG } \\
\hline & Crude & Ch Refined & Crude & Ch Refined & Crude & Ch Refined \\
\hline \multicolumn{7}{|l|}{$\begin{array}{c}\text { Press } \\
\text { Phytosterols composition } \\
(\%)\end{array}$} \\
\hline Campesterol & $6.2 \pm 0.06 a$ & $6.1 \pm 0.27 \mathrm{a}$ & $28.2 \pm 0.1 b$ & $26.5 \pm 0.39 a$ & $6.2 \pm 0.06 a$ & $6.5 \pm 0.01 b$ \\
\hline Stigmasterol & $7.8 \pm 0.08 b$ & $7.1 \pm 0.33 \mathrm{a}$ & $8.9 \pm 0.29 b$ & $7.7 \pm 0.19 a$ & $9.4 \pm 0.19 a$ & $9.4 \pm 0.17 \mathrm{a}$ \\
\hline$\beta$-Sitosterol & $61.2 \pm 0.44 a$ & $62.6 \pm 1.17 \mathrm{a}$ & $47.5 \pm 0.07 \mathrm{~b}$ & $46.3 \pm 0.74 a$ & $46.6 \pm 1.1 \mathrm{a}$ & $48.8 \pm 0.16 b$ \\
\hline$\Delta 5$-Avenasterol & $1.6 \pm 0.04$ & nd & $3.7 \pm 0.07 \mathrm{~b}$ & $2.6 \pm 0.11 \mathrm{a}$ & $0.9 \pm 0.03$ & nd \\
\hline$\Delta 7$-Stigmastenol & $18.8 \pm 0.51 \mathrm{a}$ & $20.3 \pm 1.03 a$ & $6.7 \pm 0.18 \mathrm{a}$ & $12.6 \pm 1.24 b$ & $32.5 \pm 1.58 \mathrm{a}$ & $30.9 \pm 0.33 a$ \\
\hline$\Delta 7$-Avenasterol & $4.5 \pm 0.1 \mathrm{~b}$ & $3.9 \pm 0.19 a$ & $4.9 \pm 0.12 b$ & $4.2 \pm 0.05 a$ & $4.3 \pm 0.28 \mathrm{a}$ & $4.5 \pm 0.11 \mathrm{a}$ \\
\hline Total PS content $\left(\mathrm{mg} \mathrm{kg}^{-1}\right)$ & $4476 \pm 136 b$ & $3897 \pm 225 a$ & $5225 \pm 203 b$ & $3533 \pm 63 a$ & $5284 \pm 200 b$ & $4547 \pm 298 a$ \\
\hline Tocopherols $\left(\mathrm{mg} \mathrm{kg}^{-1}\right)$ & $515 \pm 13 a$ & $489 \pm 12 b$ & $881 \pm 22 a$ & $810 \pm 20 b$ & $722 \pm 18 a$ & $679 \pm 17 b$ \\
\hline \multicolumn{7}{|l|}{$\begin{array}{c}\text { Solvent } \\
\text { Phytosterols Composition } \\
(\%)\end{array}$} \\
\hline Campesterol & $7.3 \pm 0.15 a$ & $7.2 \pm 0.25 a$ & $23.4 \pm 0.19 a$ & $23.2 \pm 0.15 a$ & $8.3 \pm 0.04 a$ & $8.5 \pm 0.19 a$ \\
\hline Stigmasterol & $11.4 \pm 0.14 b$ & $10.7 \pm 0.15 \mathrm{a}$ & $11.0 \pm 0.11 b$ & $10.2 \pm 0.17 \mathrm{a}$ & $12.6 \pm 0.25 b$ & $11.2 \pm 0.08 \mathrm{a}$ \\
\hline$\beta$-Sitosterol & $57.9 \pm 0.2 \mathrm{a}$ & $58.9 \pm 0.38 b$ & $50.9 \pm 0.35 a$ & $52.7 \pm 0.58 b$ & $48.0 \pm 0.09 a$ & $48.1 \pm 0.26 a$ \\
\hline$\Delta 5$-Avenasterol & $1.7 \pm 0.04$ & nd & $3.3 \pm 0.03 b$ & $2.5 \pm 0.13 a$ & $1.5 \pm 0.05 b$ & $1.2 \pm 0.03 a$ \\
\hline$\Delta 7$-Stigmastenol & $17.3 \pm 0.46 a$ & $18.8 \pm 0.22 b$ & $7.7 \pm 0.64 \mathrm{a}$ & $7.6 \pm 0.48 \mathrm{a}$ & $24.8 \pm 0.48 \mathrm{a}$ & $26.4 \pm 0.09 b$ \\
\hline$\Delta 7$-Avenasterol & $4.4 \pm 0.19 a$ & $4.3 \pm 0.27 a$ & $3.6 \pm 0.05 a$ & $3.9 \pm 0.18 b$ & $4.6 \pm 0.22 \mathrm{a}$ & $4.7 \pm 0.14 a$ \\
\hline Total PS content $\left(\mathrm{mg} \mathrm{kg}^{-1}\right)$ & $7272 \pm 343 b$ & $5858 \pm 310 a$ & $6678 \pm 387 b$ & $4602 \pm 238 a$ & $9249 \pm 669 b$ & $6610 \pm 458 \mathrm{a}$ \\
\hline Tocopherols (mg kg ${ }^{-1}$ ) & $517 \pm 12 a$ & $480 \pm 12 b$ & $912 \pm 23 a$ & $871 \pm 21 b$ & $784 \pm 20 a$ & $713 \pm 17 b$ \\
\hline
\end{tabular}

nd, not detected. Results for FA and PS are expressed as mean values \pm standard deviation ( $n=4$ for crude oils and $n=3$ for refined oils). Different letters indicate significant differences between crude and refined oils for each sample $(p<0.05)$, according to the Student's $t$ test.

Regarding the composition of PS, only slight but significant $(p<0.05)$ differences were found between the crude and refined oils (Table 6). The slight differences detected did not follow a definite pattern. Preferential losses of the more volatile PS, i.e., campesterol, stigmasterol, $\beta$-sitosterol and $\Delta 5$-Avenasterol, were not observed. These results are consistent with the fact that PS were mainly removed in the neutralization step and, hence, no preferential losses of particular PS took place. Despite of the slight differences observed, the oils kept their unique PS compositions, i.e., an abundance of campesterol (CAM) and of $\Delta 7$-stigmastenol (STIG), respectively.

\subsubsection{Tocopherols}

The tocopherol content also decreased after $\mathrm{ChR}$, although to a lower extent as compared to PS (Table 6). The losses found ranged between $5 \%$ and $10 \%$. These results are in agreement with other studies, where losses between $5 \%$ and $15 \%$ were detected $[7,28-33]$. Although the tocopherol content normally decreases gradually throughout the whole $\mathrm{ChR}$ process, it is known that the main cause for tocopherol losses is the deodorization step [7]. 


\subsection{Pros and Cons of Considering the PO and SO Separately}

In terms of PS contents, it would be of great interest to consider the PO and SO separately when the levels of $\mathrm{P}$ in $\mathrm{PO}$ are low enough for PhR. Taking into account, on the one hand, that PO constitutes around $70 \%$ of the oils extracted [23] and, on the other hand, that PhR may not affect the PS content, and only losses up to $30 \%$ can occur as a consequence of $\mathrm{ChR}$, processing $\mathrm{PO}$ and $\mathrm{SO}$ separately would give rise to two refined oils with both containing higher levels of PS than those in the refined blend. In addition, $70 \%$ of the crude oil (PO) would be converted into minimally processed edible oil, and the total oil losses and, in turn, the amount of waste and byproducts, would be considerably reduced. When this is not feasible and only ChR can be applied, the reduction of the PS levels in the crude blended oil due to a dilution effect would result in a refined oil with intermediate levels between those in the refined PO and SO. Another fact to be evaluated if considering $\mathrm{PO}$ and $\mathrm{SO}$ separately is the adaptation of refining conditions, which could complicate the basic operations, and two separate processing lines may be required.

\section{Conclusions}

The P levels present in the PO obtained from the new PS-enriched sunflower seeds can vary from one season to another and their reduction by bleaching to optimal levels for PhR may result as insufficient. If this is the case, the PO of the new seeds should be refined by ChR, consisted of degumming, neutralization, bleaching and deodorization. By applying optimal PhR conditions, the PO of the new cultivars can preserve their naturally occurring levels of PS and tocopherol.

The PO and SO of the new PS-enriched sunflower seeds can lose up to $30 \%$ of total $\mathrm{PS}$ as a consequence of ChR but keep the PS profile that differentiates them from common sunflower oils. Even when losses of PS are expected after ChR, the levels found in the refined oils, i.e., $3285-4547 \mathrm{mg} \mathrm{kg}^{-1}$ in the $\mathrm{PO}$ and $4602-6616 \mathrm{mg} \mathrm{kg}^{-1}$ in the SO, can be considered high compared to the established ranges by the food codex (CODEX 210-1999) for crude oils (2400-5000 $\mathrm{mg} \mathrm{kg}^{-1}$ ).

This study has been the initial stage of characterization of these new oils, aiming at evaluating the optimized refining procedures to maintain their unique sterol composition. Further studies are required to evaluate whether these new oils may have commercial advantages, mainly based on their nutritional properties.

Supplementary Materials: The following are available online at https://www.mdpi.com/article/ 10.3390/foods10081901/s1, Table S1: Elemental analysis $\left(\mathrm{mg} \mathrm{kg}^{-1}\right)(n=2)$ and chlorophyll content $\left(\mathrm{mg} \mathrm{kg}^{-1}\right)(n=2)$ of the press and solvent oils obtained in 2017 after different refining treatments. Table S2: Elemental analysis $\left(\mathrm{mg} \mathrm{kg}^{-1}\right)(n=2)$ of the press oils obtained in 2015 after bleaching treatment.

Author Contributions: Conceptualization, M.V.R.-M.; formal analysis, A.G.-G.; investigation, M.V.R.-M. and J.V.; resources, L.V.; data curation, J.V.; writing —original draft preparation, J.V., M.V.R.-M. and A.G.-G.; writing - review and editing, M.V.R.-M., J.V. and L.V.; project administration and funding acquisition, L.V. All authors have read and agreed to the published version of the manuscript.

Funding: This work was supported by research project P12-AGR-18371 from Junta de Andalucía and EU FEDER funds. Aída García also thanks Junta de Andalucía for receiving a PhD grant associated to project P12-AGR-18371.

Acknowledgments: The authors thank Irene Pérez de la Rosa, Carmen M. Olmo and M. Visitación Ortega for technical assistance.

Conflicts of Interest: The authors declare no conflict of interest. 


$\begin{array}{ll}\text { Abbreviations } & \\ & \\ \text { Phytosterol } & \text { PS } \\ \text { Oil obtained by press } & \text { PO } \\ \text { Solvent extracted oil } & \text { SO } \\ \text { free fatty acids } & \text { FFA } \\ \text { Chemical Refining } & \text { ChR } \\ \text { Physical Refining } & \text { PhR } \\ \text { phosphorous } & \text { P } \\ \text { Sunflower oil rich in campesterol } & \text { CAM } \\ \text { Sunflower oil rich in } \Delta 7 \text {-stigmastenol } & \text { STIG } \\ \text { Conventional sunflower oil } & \text { CON }\end{array}$

\section{References}

1. Moreau, R.A.; Nyström, L.; Whitaker, B.D.; Winkler-Moser, J.K.; Baer, D.J.; Gebauer, S.K.; Hicks, K.B. Phytosterols and their derivatives: Structural diversity, distribution, metabolism, analysis, and health-promoting uses. Prog. Lipid Res. 2018, 70, 35-61. [CrossRef] [PubMed]

2. Laitinen, K.; Gylling, H.; Kaipiainen, L.; Nissinen, M.J.; Simonen, P. Cholesterol lowering efficacy of plant stanol ester in a new type of product matrix, a chewable dietary supplement. J. Funct. Foods 2017, 30, 119-124. [CrossRef]

3. Uddin, M.S.; Ferdosh, S.; Haque Akanda, M.J.; Ghafoor, K.; Rukshana, A.H.; Ali, M.E.; Kamaruzzaman, B.Y.; Fauzi, M.B.; Shaarani, S.; Islam Sarker, M.Z. Techniques for the extraction of phytosterols and their benefits in human health: A review. Sep. Sci. Technol. 2018, 53, 2206-2223.

4. Roman, S.; Sánchez-Siles, L.M.; Siegrist, M. The importance of food naturalness for consumers: Results of a systematic review. Trends Food Sci. Technol. 2017, 67, 44-57. [CrossRef]

5. Carré, P. Naturalness in the production of vegetable oils and proteins. OCL 2021, 28, 10. [CrossRef]

6. Harker, M.; Holmberg, N.; Clayton, J.C.; Gibbard, C.L.; Wallace, A.D.; Rawlins, S.; Hellyer, S.A.; Lanot, A.; Safford, R. Enhancement of seed phytosterol levels by expression of an N-terminal truncated Hevea brasiliensis (rubber tree) 3-hydroxy-3-methylglutarylCoA reductase. Plant Biotechnol. J. 2003, 1, 113-121.

7. Yamaya, A.; Endo, Y.; Fujimoto, K.; Kitamura, K. Effects of genetic variability and planting location on the phytosterol content and composition in soybean seeds. Food Chem. 2007, 102, 1071-1075. [CrossRef]

8. Neelakandan, A.K.; Chamala, S.; Valliyodan, B.; Nes, W.D.; Nguyen, H.T. Metabolic engineering of soybean affords improved phytosterol seed traits. Plant Biotechnol. J. 2012, 10, 12-19. [CrossRef] [PubMed]

9. Velasco, L.; Fernández-Cuesta, Á.; Fernández-Martínez, J.M. New sunflower seeds with high contents of phytosterols. OCL 2014, 21, D604. [CrossRef]

10. González Belo, R.; Velasco, L.; Nolasco, S.M.; Izquierdo, N.G. Oil Phytosterol Concentration in Sunflower Presents a Dilution Response with Oil Weight per Grain. J. Am. Oil Chem. Soc. 2019, 96, 1115-1123. [CrossRef]

11. FAO. Oilseed Production to Rebound in 2020/21. Food Outlook: Biannu. Rep. Glob. Food Markets. 2021, p. 31. Available online: http:/ / www.fao.org/3/cb4479en/cb4479en_oilcrops.pdf (accessed on 13 August 2021).

12. Pilorgé, E. Sunflower in the global vegetable oil system: Situation, specificities and perspective. OCL 2020, 27, 34. [CrossRef]

13. Grompone, M.A. Sunflower and High-oleic Sunflower Oils. In Bailey's Industrial Oil and Fat Products, 6th ed.; Shahidi, F., Ed.; Wiley-Interscience: Hoboken, NJ, USA, 2020.

14. Salas, J.J.; Bootello, M.A.; Martínez-Force, E.; Calerón, M.V.; Garcés, R. High stearic sunflower oil: Latest advances and applications. OCL 2021, 28, 35. [CrossRef]

15. Ayerdi Gotor, A.; Berger, M.; Labalette, F.; Centis, S.; Daydé, J.; Calmon, A. Oleic conversion effect on the tocopherol and phytosterol contents in sunflower oil. Phyton-Int. J. Exp. Bot. 2016, 83, 319-324.

16. Zhang, H.; Vasanthan, T.; Wettasinghe, M. Enrichment of tocopherols and phytosterols in canola oil during seed germination. J. Agric. Food Chem. 2007, 55, 355-359. [CrossRef]

17. Fernández-Cuesta, A.; Jan, C.C.; Fernández-Martínez, J.M.; Velasco, L. Variability for seed phytosterols in sunflower germplasm. Crop Sci. 2014, 54, 190-197. [CrossRef]

18. Konuşkan, D.B. Minor bioactive lipids in cold pressed oils. In Cold Pressed Oils; Academic Press: Cambridge, MA, USA, 2020; pp. 7-14.

19. Chew, S.C. Cold-pressed rapeseed (Brassica napus) oil: Chemistry and functionality. Food Res. Int. 2020, 131, 108997. [CrossRef]

20. Van Hoed, V.; Ali, C.B.; Slah, M.; Verhé, R. Quality differences between pre-pressed and solvent extracted rapeseed oil. Eur. J. Lipid Sci. Technol. 2010, 112, 1241-1247. [CrossRef]

21. Aguirre, M.R.; Velasco, J.; Ruiz-Méndez, M.V. Characterization of sunflower oils obtained separately by pressing and subsequent solvent extraction from a new line of seeds rich in phytosterols and conventional seeds. OCL 2014, 21, D605. [CrossRef]

22. Aguirre, M.R.; Ruiz-Méndez, M.V.; Velasco, L.; Dobarganes, M.C. Free sterols and steryl glycosides in sunflower seeds with high phytosterol contents. J. Lipid Sci. Technol. 2012, 114, 1212-1216. [CrossRef] 
23. García-González, A.; Velasco, J.; Velasco, L.; Ruiz-Méndez, M.V. Characterization of press and solvent extraction oils from new sunflower seeds with modified phytosterol compositions. J. Sci. Food Agric. 2020, 101, 101-109. [CrossRef] [PubMed]

24. Codex Alimentarius. Standard For Named Vegetable Oils (CODEX STAN 210-1999), 7 July 2018. Available online: http: //www.fao.org/input/download/standards/336/CXS_210e_2015.pdf (accessed on 13 August 2021).

25. Bai, G.; Ma, C.G.; Chen, X.W. Phytosterols in edible oil: Distribution, analysis and variation during processing. Grain Oil Sci. Technol. 2021, 1, 33-44. [CrossRef]

26. Verhé, R.; Verleyen, T.; Van Hoed, V.; De Greyt, W. Influence of refining of vegetable oils on minor components. J. Oil Palm. Res. 2006, 4, 168-179.

27. Azizi, M.; Ghavami, A. The Effects of Refining Operations on Quality and Quantity of Sterols in Canola, Soyabean and Sunflower Seed Oils. J. Food Biosci. Technol. 2020, 10, 11-18.

28. Gotor, A.A.; Rhazi, L. Effects of refining process on sunflower oil minor components: A review. Oilseeds and fats. Crop. Lipids 2017, 23, D207.

29. Farr, W.E. Physical refining of vegetable oils. In Green Vegetable Oil Processing; AOCS Press: Urbana, IL, USA, $2014 ;$ pp. 159-169.

30. Kreps, F.; Vrbiková, L.; Schmidt, Ś. Influence of industrial physical refining on tocopherol, chlorophyll and beta-carotene content in sunflower and rapeseed oil. Eur. J. Lipid Sci. Technol. 2014, 116, 1572-1582. [CrossRef]

31. Kovari, K.; Denise, J.; Kemeny, Z.; Recseg, K. Physical refining of sunflower oil. Oléagineux Corps Gras Lipides 2000, 7, 305-308. [CrossRef]

32. Van Hoed, V.; Depaemelaere, G.; Ayala, J.V.; Santiwattana, P.; Verhé, R.; De Greyt, W. Influence of chemical refining on the major and minor components of rice brain oil. J. Am. Oil Chem. Soc. 2006, 83, 315-321. [CrossRef]

33. Wu, Y.; Zhou, R.; Wang, Z.; Wang, B.; Yang, Y.; Ju, X.; He, R. The effect of refining process on the physicochemical properties and micronutrients of rapeseed oils. PLoS ONE 2019, 14, e212879. [CrossRef]

34. Belur, P.D.; Iyyasami, R.; Sampath, C.; Chandrasekhar, V. Refining technologies for edible oils. In Edible Oils; CRC Press: Boca Raton, FL, USA, 2017; pp. 99-128.

35. Chew, S.C.; Nyam, K.L. Refining of Edible Oils in Lipids and Edible Oils; Academic Press: Cambridge, MA, USA, 2020; pp. $213-241$.

36. Cui, L.; Decker, E.A. Phospholipids in foods: Prooxidants or antioxidants? J. Sci. Food Agric. 2016, 96, 18-31. [CrossRef]

37. Van Duijn, G. Fate of contaminants during the refining process of vegetable oils and fats: A calculation model. J. Lipid Sci. Technol. 2016, 118, 353-360. [CrossRef]

38. Zufarov, O.; Schmidt, S.; Sekretár, S. Degumming of rapeseed and sunflower oils. Acta Chim. Slov. 2008, 1, 321-328.

39. De Greyt, W. Edible oil refining: Current and future technologies. In Edible Oil Process; John Wiley \& Sons, Ltd.: Hoboken, NJ, USA, 2013; pp. 127-151.

40. Vuorte, M.; Vierros, S.; Kuitunen, S.; Sammalkorpi, M. Adsorption of impurities in vegetable oil: A molecular modelling study. J. Colloid Interface Sci. 2020, 571, 55-65. [CrossRef]

41. Rossi, M.; Gianazza, M.; Alamprese, C.; Stanga, F. The role of bleaching clays and synthetic silica in palm oil physical refining Food Chem. 2003, 82, 291-296. [CrossRef]

42. De Clercq, N.; Moens, K.; Depypere, F.; Ayala, J.V.; Calliauw, G.; De Greyt, W.; Dewettinck, K. Influence of cocoa butter refining on the quality of milk chocolate. J. Food Eng. 2012, 111, 412-419. [CrossRef]

43. Dimic, E.; Karlovic, D.J.; Turkulov, J. Pretreatment efficiency for physical refining of sunflower seed oil. J. Am. Oil Chem. Soc. 1994, 71, 1357-1361. [CrossRef]

44. Pokorny, J.; Kalinova, L.; Dysseler, P. Determination of chlorophyll pigments in crude vegetable oils: Results of a collaborative study and the standardized method. Pure Appl. Chem. 1995, 67, 1781-1787. [CrossRef]

45. ISO 660:2020 Animal and Vegetable Fats and Oils. Determination of Acid Value and Acidity; ISO: Geneva, Switzerland, 2020.

46. García-González, A.; Velasco, J.; Velasco, L.; Ruiz-Méndez, M.V. An analytical simplification for faster determination of fatty acid composition and phytosterols in seed oils. Food Anal. Methods 2018, 11, 1234-1242. [CrossRef]

47. ISO 9936:2016 Animal and Vegetable Fats and Oils. Determination of Tocopherol and Tocotrienol Contents by High-Performance Liquid Chromatography; ISO: Geneva, Switzerland, 2016.

48. Łaska-Zieja, B.; Marcinkowski, D.; Golimowski, W.; Niedbała, G.; Wojciechowska, E. Low-Cost Investment with High Quality Performance. Bleaching Earths for Phosphorus Reduction in the Low-Temperature Bleaching Process of Rapeseed Oil. Foods 2020, 9, 603. [CrossRef] [PubMed]

49. Wildermuth, S.R.; Young, E.E.; Were, L.M. Chlorogenic acid oxidation and its reaction with sunflower proteins to form greenenic acid oxidation. Food Sci. Food Saf. 2016, 15, 829-843. [CrossRef] [PubMed]

50. Carelli, A.A.; Ceci, L.N.; Crapiste, G.H. Phosphorus to phospholipids conversion factors for crude and degummed sunflower oils. J. Am. Oil Chem. Soc. 2002, 79, 1177-1180. [CrossRef]

51. Lamas, D.L.; Crapiste, G.H.; Constenla, D.T. Changes in quality and composition of sunflower oil during enzymatic degumming process. Food Sci. Technol. 2014, 58, 71-76. [CrossRef]

52. Verleyen, T.; Sosinska, U.; Ioannidou, S.; Verhé, R.; Dewettinck, K.; Huyghebaert, A.; De Greyt, W. Influence of the vegetable oil refining process on free and esterified sterols. J. Am. Oil Chem. Soc. 2002, 79, 947-953. [CrossRef] 